\title{
NOTES
}

\section{Microevolutionary Change in the Human Pathogenic Treponemes: an Alternative Hypothesis}

\author{
DON BROTHWELL \\ Institute of Archaeology, London WC1, England
}

\begin{abstract}
Recent evidence from both archaeology and biology suggests that the taxonomy of the human pathogenic treponemes may be more complex than previously thought. An alternative evolutionary tree for the treponematoses is suggested.
\end{abstract}

During the past 50 years there has been growing interest in the ecology of the human pathogenic treponemes. Not only have they been classified on clinical evidence into a number of species, but also theories as to their evolution since Pleistocene times have been put forward. Evidence over the past decade, from both archaeology and biology, now seems to demand a reconsideration of the microevolution of treponemes (or "treponemata") of this kind.

For perhaps three or four centuries, syphilis has been a subject of considerable epidemological and clinical interest (16). Since 1905 (20), when Treponema pallidum was incriminated as the causative agent of syphilis, the taxonomy of the microorganisms producing the human treponematoses has slowly attracted attention. As Hudson (13) points out, the generic name Spirochaeta was earlier preferred by some medical biologists, but after some controversial exchanges $(19,23)$, Treponema was accepted as properly in accord with taxonomic principles, although the American Medical Association did not seem to give it official recognition in their journal until 1943.

The treponematoses are comprised of four distinct clinical entities: venereal syphilis, endemic syphilis, yaws, and pinta $(9,13-15)$. These divisions are made on pathological and clinical evidence rather than on any taxonomic relationships of the organisms themselves (Table 1). Even electron microscopy has so far failed to reveal structural differences, although these pathogenic treponemes can be distinguished from others by having pointed ends with three flagella inserted subterminally in a row (12). Failure so far to demonstrate differences of ecological significance in the microorganisms isolated in these four disease groups has resulted in differences of opinion as to whether more than one species is involved. Hudson (13), in particular, has argued that only one species, $T$. palli- dum, is involved. Hackett (9), on the other hand, considers the same range of evidence and as a result supports the following classification: Treponema pallidum Schaudinn (1905)-venereal and endemic syphilis; Treponema pertenue Castellani (1908)-yaws; "Treponema carateum" Brumpt (1939)-pinta. (Note: Names in quotation marks are not on the Approved Lists of Bacterial Names [Int. J. Syst. Bacteriol. 30:225$420,1980]$.) A variant of the latter classification is suggested by Hardy (11), who accepts that the differences between endemic and veneral syphilis are equally deserving of specific (or subspecific) distinction, and therefore he would seem to accept " $T$. endemicum" (or " $T$. pallidum endemicum") as the causative agent of endemic syphilis. Whichever side is taken in this debate, of course, most authors accept that the taxonomy of these pathogens can only be tentative, and perhaps significant steps will be made when in vitro cultures of these varieties are eventually studied. However, this does not mean that hypotheses concerned with the microevolution of these treponemes should not be advanced. Moreover, whether the four treponemal pathogens considered here are worthy of species, subspecies, or varietal status, their evolutionary relationships remain basically the same. But what is their relationship to space and time?

Previous evolutionary schemes. Although Hudson $(13,14)$ and others have commented on the apparent association between the syphilis, yaws, and pinta treponemes and climatic-cultural factors, Hackett (9) alone has constructed a workable evolutionary tree for these microorganisms. Minor alternatives to the same basic scheme are shown in Fig. 1, hypothesis A being preferred by Hackett on evidence available to him in 1963. On this overall medical information, he suggests that the pinta form was the first variant evolving from a basal treponemal stock (representatives of which do not occur in most 
TABLE 1. Clinical characteristics of the four treponematoses (modified from Hackett [9])

\begin{tabular}{|c|c|c|c|c|}
\hline Character & Pinta & Yaws & $\begin{array}{l}\text { Endemic } \\
\text { syphilis }\end{array}$ & $\begin{array}{l}\text { Venereal } \\
\text { syphilis }\end{array}$ \\
\hline Usual source of treponemes & Skin anywhere & Skin anywhere & Buccal mucosa & $\begin{array}{l}\text { Genital and } \\
\text { mucosal } \\
\text { lesions }\end{array}$ \\
\hline Size of infectious area & Large & Large & Small & Small \\
\hline \multicolumn{5}{|l|}{ Duration of } \\
\hline $\begin{array}{l}\text { Infectiousness of individ- } \\
\text { ual lesions }\end{array}$ & Many years & A few months & A few months & A few months \\
\hline $\begin{array}{l}\text { Infectiousness of patients, } \\
\text { including infectious re- } \\
\text { lapses }\end{array}$ & Many years & $3-5 \mathrm{yr}$ & $3-5 \mathrm{yr}$ & $3-5 \mathrm{yr}$ \\
\hline Latency $^{a}$ & Absent & Characteristic & Characteristic & Characteristic \\
\hline \multicolumn{5}{|l|}{ Lesions: } \\
\hline Initial, site & Exposed skin & Skin of legs & Mouth? & Genital \\
\hline Generalized skin, extent & Extensive & Extensive & Limited & Moderate \\
\hline Genital, occurrence & Unusual & Scanty & Scanty & Frequent \\
\hline $\begin{array}{l}\text { Buccal mucosal, occur- } \\
\text { rence }\end{array}$ & Absent & $\begin{array}{l}\text { Scanty or } \\
\text { absent }\end{array}$ & Moderate & Scanty \\
\hline $\begin{array}{l}\text { Palmar and plantar hyper- } \\
\text { keratoses, occurrence }\end{array}$ & Absent & Frequent & Scanty & Scanty \\
\hline Bone, occurrence & Absent & Moderate & Moderate & Scanty \\
\hline $\begin{array}{l}\text { Juxta-articular nodules, } \\
\text { occurrence }\end{array}$ & Absent & Frequent & Scanty & Scanty \\
\hline $\begin{array}{l}\text { Heart, brain, and other } \\
\text { viscera, occurrence }\end{array}$ & Absent & Absent & $\begin{array}{l}\text { Scanty and } \\
\text { mild, } \\
\text { or absent }\end{array}$ & Moderate \\
\hline Congenital transmission & Absent & Absent & Absent & Present \\
\hline $\begin{array}{l}\text { Age group for most infec- } \\
\text { tions }\end{array}$ & Children & Children & Children & Adults \\
\hline
\end{tabular}

${ }^{a}$ Latency in a communicable disease is a stage in its course in which there is evidence of infection such as seroreactivity but no clinically detectable active lesions.

modern populations). By further mutation and divergence, yaws organisms evolved in humid, warm environments, and then endemic syphilis evolved from yaws as a means of adapting to arid, hot climates. Venereal syphilis is seen as a late culmination of microevolutionary change, linked with climatic change, decreasing endemic syphilis, denser settlement, more clothing, and perhaps even changing sexual behaviour. Willcox $(24,25)$ echoes this view in that he sees treponemal divergence occurring sequentially as a result of mutation and the selection of a pathological state best suited for the continuing transmission from host to host in the particular environment.

Some years ago, modification of Hackett's original changes in the spatial distribution of the treponematoses through time seemed to me (2) to be essential, as various archaeological discoveries were casting some doubt on the interpretations arrived at purely by extrapolating back into time from modern clinical evidence. Further archaeological evidence leads me to suggest that the time has arrived for at least a consideration of alternative hypotheses concerning treponemal evolution, especially if they would seem to fit both clinical and archaeological information now available. Paleopathological discoveries in the last 10 years related to the question of treponemal microevolution and dispersal have been principally as follows.

(i) Osteological evidence in the Marquesas islands, Borneo (3), and Tonga (13) suggesting infection by one or more varieties of Treponema confirms the previous claim of a yaws type of disease in the Marianas islands (22), and it now looks certain that early Southeast Asian populations had gradually extended the treponeme range into the central Pacific.

(ii) Further studies on Amerindian skeletons from North and Central America have established beyond reasonable doubt that treponeme varieties in the Pre-Columbian New World (5) included one which produced bone lesions distinctive of a treponematosis. As some of these cases are from arid zones in Mexico (4) and Arizona (and also probably Peru) (26), treponemal differentiation was clearly adapting here to hot and dry as well as to more humid climates (as experienced by the Illinois and Florida Amerindians) (17). Moreover, this also seems to demonstrate that pinta was not the only early New 


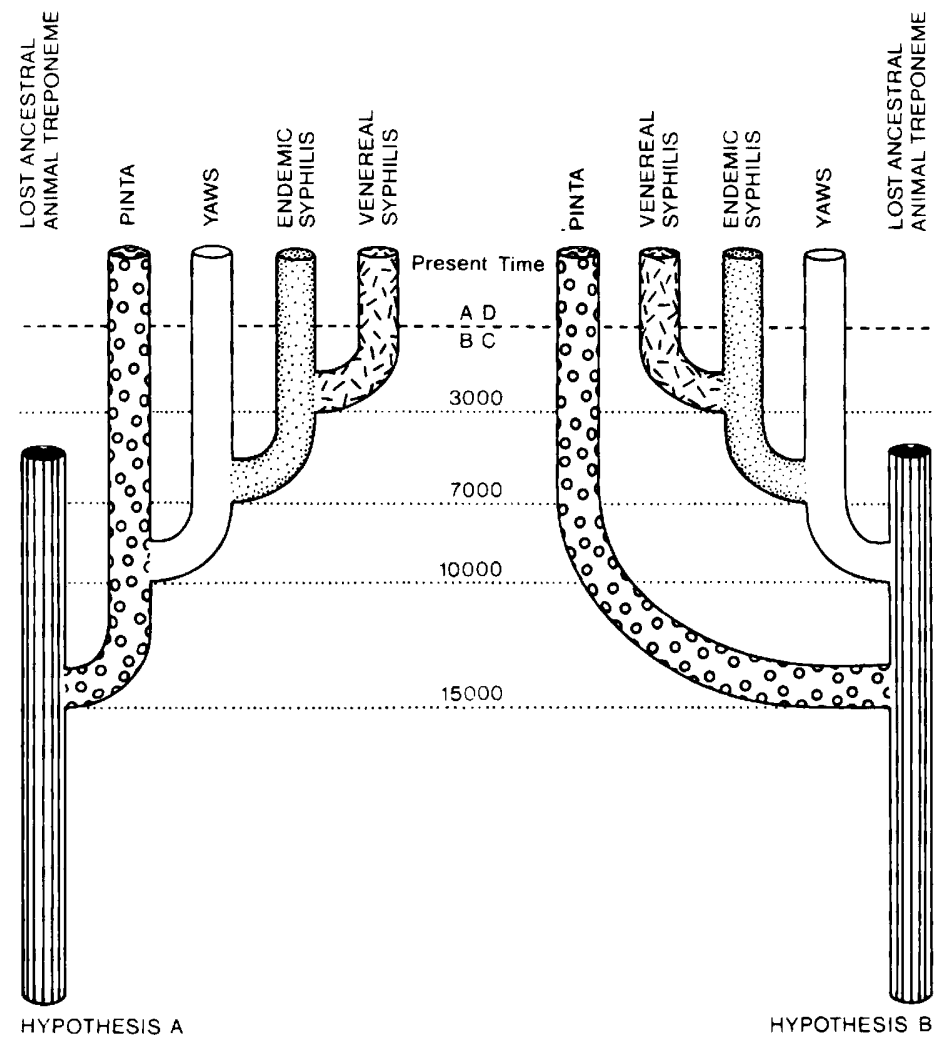

FIG. 1. Hypotheses $A$ and B, as suggested by Hackett (9), to explain the microevolution of human pathogenic treponematoses.

World treponeme variety, and from the valley of Tehuacan in Mexico (1) there is clear evidence of a bone-changing treponematosis at least 2,200 years ago. To me, this is a very important point which so far has not been considered in relation to treponeme evolution.

(iii) Although the Aswan project in Egypt and Nubia has resulted in large numbers of extra skeletons being available for study, there still remains no evidence of early treponemal disease in Africa.

(iv) Large numbers of skeletons continue to be excavated in northern Europe, and there is still no evidence of treponemal disease until late medieval times (circa A.D. 1200 to 1500). A recent excavation at the site of the medieval church of St. Helen-on-the-Walls in York (J. Dawes, personal communication) would appear to substantiate other evidence from Chichester that, prior to Columbus, a bone-changing treponeme had arrived in northern Europe.

Discussion. Taking this new information in conjunction with what is known of the biology of modern treponemes, it would seem that some modification of previous hypotheses is possible, if not desirable.

From clinical evidence, it is established that four main pathogenic varieties of Treponema affect humans today. The probable Pleistocene isolation of populations in such areas as New Guinea and Australia and the development in these communities of yaws-endemic syphilis diseases suggest that some form of treponematosis has affected humans since at least late Pleistocene times. If treponemes were carried into the Americas by early Paleo-Indian groups (rather than having had a trans-Pacific entry into the New World), then again a Pleistocene antiquity is suggested. On available archaeological evidence, treponemes causing bone changes were certainly present in eastern Asia by about A.D. 500 and in the New World by 200 B.C., if not much earlier. It could be argued that the absence of skeletal evidence of treponematosis in Africa might indicate that the less devastating condition, pinta, was the only one affecting these communities until quite later on, but the alternative one of an absence of pathogenic trepo- 
nemes is equally likely. This argument similarly applies to Europe. If the pinta variant had been well distributed in parts of the Old World, it would seem to me very surprising if some, perhaps more isolated, groups of people did not display it today. I make this point because it seems relevant to the proper construction of an alternative hypothesis concerning treponemal microevolution.

Turning to the New World, it is no longer possible to disclaim the occurrence of Pre-Columbian treponematosis of a kind which left clear evidence in bone pathology (as defined by Hackett's guidelines [10]). As varieties of Treponema eventually existed in populations occupying both hot and humid as well as arid environments, there seems a case for accepting the evolution of T. pallidum and perhaps even $T$. pertenue strains, although this is not to suggest that these early variants need be identical with the modern yaws-syphilis varieties studied mainly in non-Amerindian communities. As far as the distribution of these parasites is concerned, it is significant that they clearly overlap that of " $T$. carateum" (pinta). In the case of Mexico, it is difficult to argue that pinta does not extend into zones represented by the earlier finds. A further point, and one which has been neglected, is that " $T$. carateum" occurs in communities populated by those who are by no means simply "remote jungle people" as is usually implied. Much of the area which is important in the evaluation of pinta was at the forefront of cultural changes in the Americas. This same region was involved in the development of early agricultural societies and later of densely populated and advanced empires.

It is thus difficult to avoid, from this New World evidence, the need to construct an alternative hypothesis for the evolution of the pathogenic human treponemes. Figure 2 gives a tentative alternative to Hackett's evolutionary tree. It will be seen that the major difference is in positioning " $T$. carateum" (pinta) as a final stage in the treponemal sequence rather than in a basal position. As pinta has restricted distribution in Amerindian groups and as it is found in areas where advanced early societies have occurred and where evidence of bone-changing treponematosis has been found, it seems important to view the condition in relation to these other factors. The facts that the pinta treponeme mainly causes skin lesions and is especially characterized by a long period of (but probably not great) infectiousness do not contradict this scheme. One could argue, in fact, that " $T$. carateum" had become the most specialized form, and at the same time more ideally host adapted, in becoming so localized in the cooler, more external area of the body. Even with T.pallidum the skin offers an optimum temperature for the retention of infectivity (21). Further adaptive advantages of " $T$. carateum" are that it is spread by direct contact and possibly by an insect vector and that it often establishes itself in childhood.

Experimental evidence is also relevant here. It is possible that the pathogenic rabbit treponeme, T. paraluis-cuniculi, has evolutionary links with the human varieties being discussed. In view of this, it is interesting to note that, unlike the other three types, "T. carateum" produces no infection in rabbits (11), a fact which might suggest a greater evolutionary distance from $T$. paraluis-cuniculi.

As far as the New World is concerned, then, I suggest that one can reasonably postulate the occurrence in Pre-Columbian times of three treponemes. In view of the present eastern Asian evidence, it does not seem necessary to suggest independent evolution of all three forms but rather to derive a basal $T$. pertenue $T$. pallidum stock from the areas which were to people the Americas. This would explain the occurrence of bone-changing treponematosis in some Amerindian communities of North America, well outside the range for pinta. After this initial intrusion of treponemes, there could have been 10,000 years or more of independent microevolution, with the eventual emergence of pinta as a treponeme most adapted to survival in humans but with minimum damage to the host.

In the Old World, with different human populations and environmental factors, " $T$. cara. teum" did not evolve. Instead, with the expansion of the Classical World, the widening of trade horizons, and eventually the Holy Wars, the treponemes were transferred beyond their natural ranges and met further adaptive challenges. It was for this reason that syphilis was late intruding into Europe, and the as yet rare medieval skeletal evidence suggests that changes were demanded of the endemic form if it was to survive in northern cultures and climates. The adaptive strategy was to concentrate on adults and to rely on genital contact or congenital transmission.

Conclusion. Prior to European voyaging in late medieval times, then, there would appear to be evidence of three treponemes in both the Old World and the New World, with two forms being shared by both. It could be that the long period of separation of some treponemal stocks led to further microevolution, even if marked clinical differences are not yet known. It may be significant in this respect that immunological differences in these treponemes are now being noted at an intraspecific level (11), and certainly this 


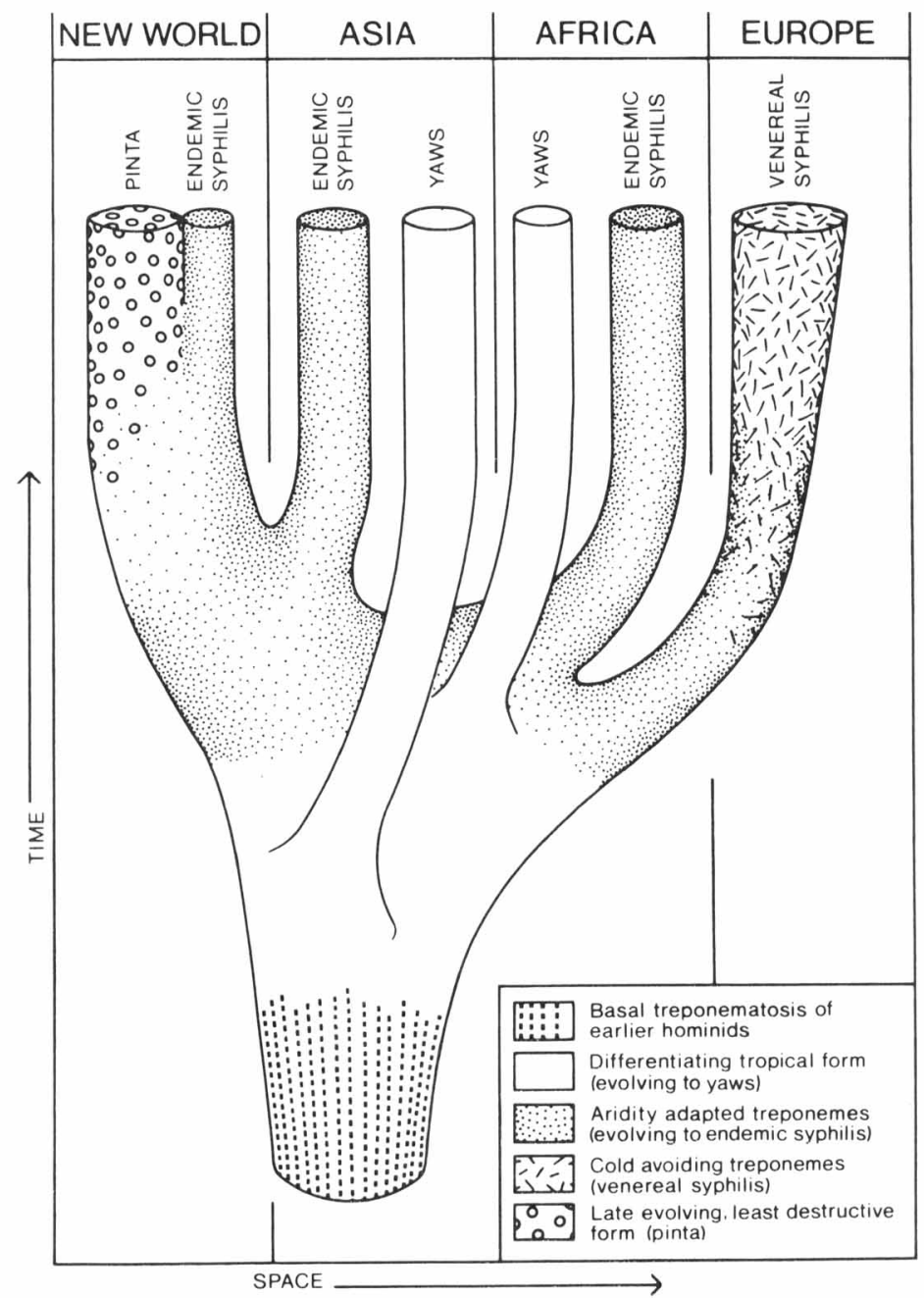

FIG. 2. Alternative evolutionary tree for the treponematoses as suggested in this paper.

casts doubt upon the value of the present species names $T$. pallidum, $T$. pertenue, and "T. carateum." As Fig. 2 suggests, there may be six lines of Treponema which have been separated over time and space, but how long yaws in New Guinea (7) and Africa (8) has undergone separate evolution, or endemic syphilis in Southwest Asia (14) and Australia (9), remains to be seen. And what earlier varieties have been completely replaced? Clearly, the taxonomy of the human pathogenic treponemes may be more complex than previously thought. Species names seem less importnat at this stage than attempting to relate the clinical and archaeological data with a satisfactory evolutionary scheme.

I thank Arturo Romano of the Mexican National Museum of Anthropology for support and help in studying the important collection of ancient treponematosis specimens in his care. Similarly, I appreciate information from Jean Dawes of the York Archaeological Trust relating to late medieval British treponematosis. I should also like to record that, in the past, I have greatly benefited from information and encouragement from $\mathrm{E}$. H. Hudson. The hypothesis presented here was discussed at a seminar in the Sub-Department of the History of Medicine at University College London during 1978 , and I am grateful for the encouraging responses from colleagues.

\section{REPRINT REQUESTS}

Address reprint requests to: Institute of Archaeology, 3134 Gordon Square London, WC1H OPY, England.

\section{LITERATURE CITED}

1. Anderson, J. W. 1967. The human skeletons, p. 91-113. In D. S. Byers (ed.), The prehistory of the Tehuacan Valley, vol 1. Environment and subsistence. University of Texas Press, Austin.

2. Brothwell, D. R. 1970. The real history of syphilis. Sci. J. 6:27-33.

3. Brothwell, D. R. 1976. Further evidence of treponema- 
tosis in a pre-European population from Oceania. Bull. Hist. Med. 50:435-442.

4. Brothwell, D. R. 1978. Possible evidence of the parasitisation of early Mexican communities by the micro-organism Treponema. Bull. Inst. Archaeol. (London) 15: 113-130.

5. Brothwell, D. R., and R. Burleigh. 1975. Radiocarbon dates and the history of treponematosis in man. $\mathrm{J}$. Archeol. Sci. 2:393-396.

6. Garner, M. F., J. L. Backhouse, P. M. Moodie, and G. J. Tibbs. 1972. Treponemal infection in the Australian Northern Territory aborigines. Bull. W.H.O. 46:285293.

7. Garner, M. F., R. W. Hornabrook, and J. L. Backhouse. 1972. Prevalence of yaws on Kar Kar Island, New Guinea. Br. J. Vener. Dis. 48:350-355.

8. Hackett, C. J. 1951. Bone lesions of yaws in Uganda. Blackwell Scientific Publications Itd., Oxford.

9. Hackett, C. J. 1963. On the origins of the human treponematoses (pinta, yaws, endemic syphilis and venereal syphilis). Bull. W.H.O. 29:7-41.

10. Hackett, C. J. 1976. Diagnostic criteria of syphilis, yaws and treponarid (treponematoses) and of some other diseases in dry bones (for use in osteoarchaeology). Springer-Verlag, Berlin.

11. Hardy, P. H. 1976. Pathogenic treponemes, p. 107-119. In R. C. Johnson (ed.), The biology of parasitic spirochaetes. Academic Press, Inc., New York.

12. Hovind-Hougen, K. 1976. Treponema and Borrelia morphology , p. 7-18. In R. C. Johnson (ed.) The biology of parasitic spirochaetes. Academic Press, Inc., New York.

13. Hudson, E. H. 1946. Treponematosis. Oxford University Press, New York.

14. Hudson, E. H. 1958. Non-venereal syphilis. A sociological and medical study of bejel. E. \& S. Livingstone Ltd.,
Edinburgh.

15. Johnson, R. C. (ed.). 1976. The biology of parasitic spirochaetes. Academic Press, Inc., New York.

16. Lancereaux, E. 1868. A treatise on syphilis, vol. 1. New Sydenham Society, London.

17. Morse, D. 1967. Two cases of possible Treponema infection in prehistoric America, p. 48-60. Tech. Ser. no. 7 Museum of Northern Arizona, Flagstaff.

18. Pietrusewsky, M. 1969. An osteological study of crania and infracranial remains from Tonga. Rec. Auckland Inst. Mus. 6:287-402.

19. Pusey, W. A. 1916. Spirocheta pallida or Treponema pallidum. J. Am. Med. Assoc. 67:1621.

20. Schaudin, F., and E. Hoffmann. 1905. Vorlaufiger Bericht über das Vorkommen von Spirochaeten in syphilitischen Krankheitsprodukten und bei Papillomen. Arb. Gesundh. Amte. (Berlin) 22:527-534.

21. Smith, H. 1976. The determinants of microbial pathogenicity in relation to spirochetal disease, p. $240-247$. In R. C. Johnson (ed.) The biology of parasitic spirochaetes. Academic Press, Inc., New York.

22. Stewart, T. D., and A. Spoehr. 1952. Evidence on the paleopathology of yaws. Bull. Hist. Med. 26:538-553.

23. Stiles, C. W. 1917. Treponema pallidum and Spirocheta pallida, from the standpoint of the international rules of zoological nomenclature. J. Am. Med. Assoc. 68:57.

24. Willcox, R. R. 1974. Changing patterns of treponemal disease. Br. J. Vener. Dis. 50:169-178.

25. Willcox, R. R. 1976. The epidemiology of the spiroche toses. A world-wide view, p. 130-155. In R. C. Johnson (ed.), The biology of parasitic spirochaetes. Academic Press, Inc., New York.

26. Williams, H. U. 1936. The origin of syphilis; evidence from diseased bones. Arch. Dermatol. Syphilol. 33:783787 